\title{
ANALISIS KELEMBAGAAN PENGELOLA TAMAN NASIONAL LAUT KEPULAUAN SERIBU
}

\section{Institutional Analysis of the 'Kepulauan Seribu' National Marine Park Management}

\author{
"Hariyani Sambali', Fredinan Yulianda², Dietriech G. Bengen² dan M. Mukhlis Kamal² \\ ${ }^{1}$ Fakultas Perikanan dan Ilmu Kelautan Universitas Sam Ratulangi Manado \\ ${ }^{2}$ Dosen FPIK Institut Pertanian Bogor, Bogor \\ "email: hari.sambali@gmail.com \\ Diterima 23 April 2014 - Disetujui 6 Juni 2014
}

\begin{abstract}
ABSTRAK
Permasalahan kewenangan secara kelembagaan dalam pengelolaan kawasan konservasikhususnya Taman Nasional Kepulauan Seribu (TNKpS) masih terus mengemuka, hal ini dapat berpotensi konflik kewenangan yang berdampak terhadap keberlanjutan pengelolaan. Penelitian ditujukan untuk mengetahui kelembagaan yang paling berwenang dalam pengelolaan TNKpS dan dampak penambangan karang terhadap sumber daya terumbu karang.Pengumpulan data dilakukan dengan menggunakan metode wawancara dan pengisian kuisioner. Analisis data menggunakan metode ISM (Interpretative Structural Modelling) dan data lapangan menggunakan metode Line Intercept Transects (LIT). Hasil penelitian menunjukkan Kementerian Kehutanan dan Pemerintah Daerah adalah kelembagaan yang mempunyai pengaruh kuat terhadap keberlangsungan pengelolaan Taman Nasional Kepulauan Seribu. Agar pengelolaan sumber daya Taman Nasional Kepulauan Seribu dapat berkelanjutan, makaelemen Tujuan Program yang dapat dirujuk sebagai kebijakan pengelolaan bersama kedua kelembagaan tersebut adalah Kelestarian Sumber daya Taman Nasional.
\end{abstract}

Kata Kunci: konservasi, taman nasional laut, interpretative structural modelling

\begin{abstract}
Institutional authority is one of the problem in the management of protected areas, especially on Kepulauan Seribu National Park does still exist and it could have an impact on management sustainability because of any potential authority conflicts. The objectives of this study are: (1) analyzing and determining the most influential management institution of TNKpS; and (2) analyzing the impact of coral mining at coral reef resources.Data was collected using interviews and questionnaires. Data was analyzed using ISM (Interpretative Structural Modelling) for institutional dataand Line Intercept Transects (LIT) for field data. The results showed that Ministry of Forestry and Local Government are the most influence institution in the authority context for management of Kepulauan Seribu National Marine Park. Ensuring the sustainability of Kepulauan Seribu National Park resource thenthe program elements that can be referred as joint resource management policies of the two institutions is the National Park Resource Sustainability.
\end{abstract}

Keywords: conservation, institutional, interpretative structural modelling, national park 


\section{PENDAHULUAN}

Kawasan konservasi sangat erat kaitannya dengan pemanfaatan sumber daya alam yang tujuan utamanya agar dapat dicapai kesejahteraan bagi masyarakat dengan tetap mempertahankan kelestarian fungsi lingkungan. Sumber daya alam sangat berperan dalam menunjang perekonomian nasional, sehingga mempunyai peran sebagai penopang sistem kehidupan dan modal pertumbuhan ekonomi. Salah satu bentuk kawasan konservasi adalah Taman Nasional Kepulauan Seribu (TNKpS) yang termasuk dalam ketegori kawasan yang dilindungi. TNKpS sejak tahun 2002 ditetapkan sebagai salah satu taman nasional laut, secara yuridis terletak di Kabupaten Administrasi Kepulauan Seribu Propinsi DKI Jakarta telah dirasakan manfaatnya oleh masyarakat ditinjau dari segi sosial, ekonomi, budaya dan manfaat fisik. Namun demikian dalam pengelolaannya masih dijumpai beberapa permasalahan pokok yang merupakan potensi konflik, terutama konflik kewenangan.

Pengelolaan TNKpS pada tataran kebijakan Pemerintah Pusat (Kementerian Kehutanan) melalui Balai Taman Nasional Kepulauan Seribu (BTNKpS) sebagai pengelola dan Pemerintah Daerah mempunyai kebijakan yang berbeda berkaitan dengan pengelolaan kawasan TNKpS. Disharmoni berkaitan dengan kewenangan pengelolaan antara kedua pemangku kepentingan tersebut menyebabkan peraturan sulit diterapkan lintas sektoral. Konflik kewenangan dalam pengelolaan kawasan TNKpS pada akhirnya mengakibatkan kinerja pengelolaan kurang optimal. Beberapa aspek yang diidentifikasi yang menjadi latar belakang konflik kewenangan tersaji pada Tabel 1 .

Hal ini jika tidak dilakukan pembenahan maka permasalahan ini dapat menjadi ancaman terhadap pengelolaan TNKpS yang pada akhirnya akan berdampak pada keberlangsungan sumber daya. Dalam rencana pengelolaan Taman Nasional Kepulauan Seribu tahun 1999 dinyatakan bahwa isu konflik dalam pengelolaan kawasan TNKpS adalah masih tumpang tindihnya pemanfaatan ruang dan benturan kepentingan para pemangku kepentingan yang berdampak terjadinya perambahan di zona inti dan zona pemanfaatan (BTNKpS, 2011). Hal ini telah dikemukakan sebelumnya oleh Amanah (2004) adanya tumpang tindih pemanfaatan dan kewenangan antar berbagai pihak dalam pengelolaan kawasan Kepulauan Seribu. Selanjutnya Cadoret (2009) menyatakan isu konflik merupakan tantangan dalam pengelolaan baik secara sosial, politik dan lingkungan karena konflik merupakan bagian integral dari semua kegiatan pengelolaan. Hilyana (2011), menyatakan dalam pengelolaan kawasan konservasi di Gili Sulat-Gili Lawang Kabupaten Lombok Timur masih rendahnya sinkronisasi kebijakan lintas sektoral. Gomes et al. (2008), mensinyalir bahwa pemerintah terkadang tidak konsisten dalam perencanaan, pengawasan dan tingkat implementasi kebijakan.

Implikasi dari permasalahan kewenangan dalam pengelolaan adalah tekanan yang kuat berupa eksplorasi dan eksploitasi sumber daya alam sehingga terjadi ancaman degradasi fisik habitat, pencemaran perairan, tangkap lebih (over fishing), pemanfaatan zona peruntukan, penambangan pasir dan batu karang untuk dijadikan bahan bangunan. Badan Perencanaan dan Pembangunan Daerah (Bappeda) DKI (2001) sejak awal telah mengindikasikan terjadinya penyimpangan pemanfaatan lahan dan sumber daya dari rencana peruntukannya, antara lain pemanfaatan sumber daya perikanan berlebihan, sehingga menimbulkan usaha lain yang merusak sumber daya laut terutama terumbu karang yang merupakan salah satu ikon pariwisata TNKpS.

Makalah ini bertujuan mengidentifikasi kelembagaan yang paling berperan dalam pengelolaan dan keberlanjutan pengelolaan kawasan Taman Nasional Kepulauan Seribu, serta strategi yang dapat dikembangkan dalam pengelolaan sumber daya alam TNKpS dengan kebijakan pengelolaan. Adanya kebijakan bersama yang nantinya sebagai pedoman dalam mengatur, mengarahkan serta mengendalikan berbagai aktivitas pengelolaan tentunya akan berimplikasi yang baik untuk ekosistem dan sumber daya pesisir, serta mampu menunjang usaha pemerintah, pengelola taman nasional serta masyarakat yang mendiami kawasan secara berkelanjutan.

\section{METODOLOGI}

Analisis kelembagaan menggunakan metode Interpretative Structural Modelling (ISM) yang dikembangkan oleh Saxena et al. (1992) untuk mengetahui kelembagaan yang paling berperan dalam pengelolaan Taman Nasional Laut Kepulauan Seribu. Metodologi dan teknik ISM menghasilkan struktur hirarki elemen sistem dan klasifikasi sub elemen kunci berdasarkan hasil wawancara dan diskusi dengan pakar yang diseleksi secara sengaja (purposive sampling) yaitu Bupati Kabupaten 
Tabel 1. Aspek-Aspek yang Tidak Harmonis Teridentifikasi dari Pihak Pemerintah Daerah dan BTNKpS, Sejak Tahun 2002 - Sekarang.

Table 1. Unharmonized Aspects Identified Between Local Government and Kepulauan Seribu National Park Authority, Since 2002 to Date.

\begin{tabular}{|c|c|c|c|}
\hline No. & Objek/Object & $\begin{array}{c}\text { Kab. Administrasi Kep. Seribu/ } \\
\text { Administration Regency of } \\
\text { Seribu Islands }\end{array}$ & TNKpS \\
\hline \multirow[t]{3}{*}{1} & $\begin{array}{l}\text { Dasar hukum / } \\
\text { Primary legislation }\end{array}$ & $\begin{array}{l}\text { UU No.32 Tahun } 2004 \text { / Act } \\
\text { No.32 of } 2004\end{array}$ & $\begin{array}{l}\text { UU No.5 Tahun } 1990 \text { / } \\
\text { Act No.5 of } 1990\end{array}$ \\
\hline & & $\begin{array}{l}\text { UU No. } 26 \text { Tahun } 2007 \text { / Act No. } \\
26 \text { of } 2007\end{array}$ & \\
\hline & & $\begin{array}{l}\text { UU No. } 27 \text { Tahun } 2007 \text { / Act } \\
\text { No. } 27 \text { of } 2007\end{array}$ & \\
\hline 2 & $\begin{array}{l}\text { Dasar acuan } \\
\text { rencana operasional/ } \\
\text { Basic reference of } \\
\text { operational plan }\end{array}$ & $\begin{array}{l}\text { Perda No.1 Tahun } 2012 \text { / Local } \\
\text { government decree No. } 1 \text { of } 2012\end{array}$ & $\begin{array}{l}\text { RPTN } 1999 \text { - } 2019 \text { / Management } \\
\text { plan of National park 1999-2019 }\end{array}$ \\
\hline 3 & $\begin{array}{l}\text { Pemanfaatan } \\
\text { kawasan perairan/ } \\
\text { Utilization of the } \\
\text { waters }\end{array}$ & $\begin{array}{l}\text { Basis demografi dan aktivitas } \\
\text { ekonomi / Demographics and } \\
\text { economic activities }\end{array}$ & Berbasis zonasi / Zoning based \\
\hline 4 & $\begin{array}{l}\text { Pulau kecil (daratan)/ } \\
\text { Small Island (land) }\end{array}$ & $\begin{array}{l}\text { Dikembangkan untuk } \\
\text { kepentingan ekonomi / } \\
\text { Developed to economic interest }\end{array}$ & $\begin{array}{l}\text { Tidak masuk kewenangan taman } \\
\text { nasional tetapi dapat mempengaruhi } \\
\text { kawasan TN / Not in the national } \\
\text { park authority but can affect to } \\
\text { management of national park }\end{array}$ \\
\hline 5 & $\begin{array}{l}\text { Terumbu karang/ } \\
\text { Coral reef }\end{array}$ & $\begin{array}{l}\text { Boleh dimanfaatkan dan } \\
\text { ditambang / Exploited and mined }\end{array}$ & $\begin{array}{l}\text { Degradasi dan pemanfaatn dan } \\
\text { jasa terbatas / Degradation and } \\
\text { utilization and limited of services }\end{array}$ \\
\hline 6 & $\begin{array}{l}\text { Tata ruang / Land } \\
\text { use }\end{array}$ & $\begin{array}{l}\text { Basis pemanfaatan / Base of } \\
\text { utilization }\end{array}$ & Sistem zonasi / Zoning system \\
\hline 7 & $\begin{array}{l}\text { Masyarakat / } \\
\text { Community }\end{array}$ & $\begin{array}{l}\text { Perlakuan umum seperti di luar } \\
\text { kawasan konservasi / Treated as } \\
\text { non reserves area }\end{array}$ & $\begin{array}{l}\text { Tidak berkewajiban diakomodir / Not } \\
\text { required to be accomodated }\end{array}$ \\
\hline 8 & Perikanan / Fisheries & $\begin{array}{l}\text { Perlakuan umum / General } \\
\text { treatment }\end{array}$ & Tidak diakomodir / Not accomodated \\
\hline 9 & Pasir laut / Sand & Dilarang diambil / Prohibited & Pemanfaatan terbatas / Limited use \\
\hline
\end{tabular}

Administrasi Kepulauan Seribu dan Kepala Balai Taman Nasional Kepulauan Seribu. Penentuan sub elemen juga melibatkan staf pegawai dilingkungan Propinsi DKI Jakarta, Pemerintah Kabupaten dan BTNKpS (17 orang). Informasi dari sistem yang dikaji kemudian distrukturisasi dalam bentuk matriks yang disebut Structured Self Interaction Matrix (SSIM) yang menggambarkan hubungan kontekstual antar sub elemen dan elemen-elemen sistem. SSIM kemudian ditransformasi menjadi reachability matrix (RM), yaitu matriks bilangan biner yang dikaji memiliki sifat transvitas dan reflektivitas, dan penilaiannya menggunakan empat simbol $\mathrm{V}, \mathrm{A}$, $\mathrm{X}$, dan $\mathrm{O}$ yang mengikuti aturan :

$\mathrm{V}$ jika $\mathrm{e}_{i j}=1$ dan $\mathrm{e}_{j i}=0$ (sub elemen (1) mempengaruhi sub elemen (2), tetapi tidak sebaliknya)

A jika $e_{i j}=0$ dan $e_{j i}=1$ (sub elemen (2) mempengaruhi sub elemen (1), tetapi tidak sebaliknya) 
$X$ jika $e_{i j}=1$ dan $e_{j i}=1$ (sub elemen (1) dan sub elemen (2) saling mempengaruhi

$\mathrm{O}$ jika $\mathrm{e}_{i j}=0$ dan $\mathrm{e}_{j i}=0$ (sub elemen (1) dan sub elemen (2) tidak saling mempengaruhi

Nilai $e_{i j}$ adalah 1 ada hubungan kontekstual antara sub elemen ke-i dan ke-j

Nilai $e_{i j}$ adalah 0 tidak ada hubungan kontekstual antara sub elemen ke-i dan ke-j

Pengambilan data lapangan untuk menghitung laju kerusakan akibat penambangan karang dilakukan dengan menggunakan SCUBA dan underwater camera, serta wawancara dengan pelaku penambangan karang (23 orang). Pengukuran tutupan karang menggunakan metode Line Intercept Transect (LIT) dan nilainya dihitung berdasarkan rumus English et al. (1997) yaitu:

$$
L_{i}=\frac{n_{i}}{L} \times 100 \%
$$

$L_{i}=$ Persentase penutupan biota ke-i; / $L_{i}=$ Percentage cover of biota to-i;

$n_{i}=$ Panjang total kelompok biota karang ke-i; $/ n_{i}$ Total length of the reef biota group to-i;

$L=$ Panjang total transek garis/ $L$ Total length of the transect line

Pengukuran jumlah batu karang yang dapat diambil oleh penambang dilakukan secara langsung in situ ketika penambang sedang bekerja, kemudian dipadukan dengan hasil wawancara terhadap para penambang yang rata-rata menambang batu karang sebesar $24,1 \mathrm{~m}^{3} /$ bulan/orang. Diasumsikan $1 \mathrm{~m}^{3}$ batu karang berukuran sama dengan luas $1 \mathrm{~m}$ x $3 \mathrm{~m}$ di alam. Penelitian dilakukan pada periode bulan Juni 2011 sampai dengan Oktober 2012 dengan melibatkan responden yaitu nelayan dan masyarakat (285 orang) berkaitan dengan kegiatan yang dilakukan para penambang dan dampaknya terhadap hasil tangkapan ikan nelayan, serta peran dan kebutuhan masyarakat akan batu karang untuk mereklamasi pantai dan perumahan.

\section{HASIL DAN PEMBAHASAN}

\section{Elemen Kelembagaan}

Hasil analisis dengan metode ISM untuk kelembagaan atau pelaku, Gambar 1 memperlihatkan bahwa sub elemen kunci dari elemen kelembagaan adalah Kementerian Kehutanan (L1) dan Pemerintah Kabupaten Administrasi Kepulauan Seribu (L3) atau merupakan elemen yang paling berpengaruh, kemudian diikuti oleh Pemerintah Propinsi DKI Jakarta (L2) dan Balai Taman Nasional Kepulauan Seribu (L4) yang masuk dalam sektor IV sebagai independent factor (strong driver-weak dependent variables) yang memiliki kekuatan penggerak yang besar terhadap keberhasilan program pengelolaan (Gambar 2).

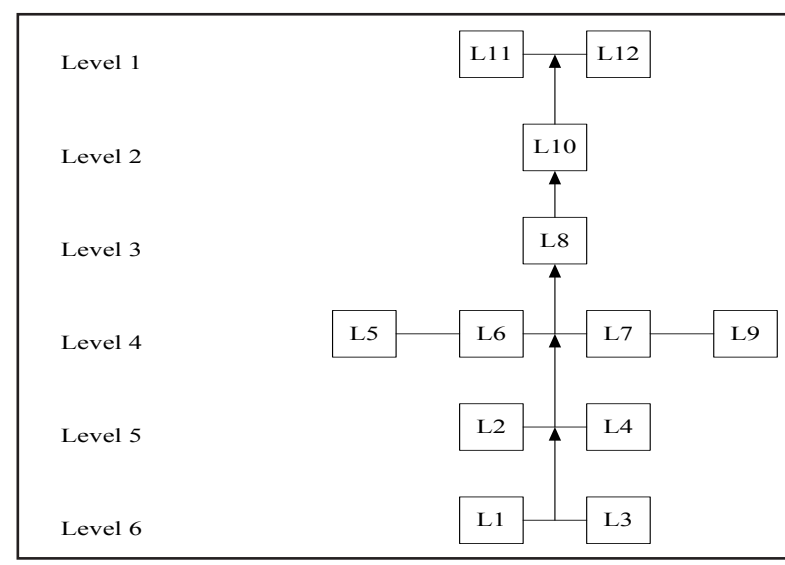

Gambar 1. Diagram Model Struktural Kelembagaan Pengelolaan Taman Nasional Kepulauan Seribu.

Figure 1. Diagram Model of Structural Instutional on Management of The Kepulauan Seribu National Marine Park.

Kementerian Kelautan dan Perikanan (L5), Masyarakat/nelayan (L6), Perguruan tinggi (L7), dan Lembaga Kemasyarakatan Non Formal (SPKP, APL, Sentra Penyuluh) (L9) sebagai linkage factor (strong driver-strong dependence variables). Lembaga Swadaya Masyarakat (L8), LIPI (L10), Stasiun Meteorologi Maritim Tanjung Priok (L11), dan Badan Informasi Geospasial (L12) merupakan dependen factor (weak driver-strongly dependent variables). Analisis juga menunjukkan Kementerian Kehutanan yang membawahi pengelola taman nasional merupakan faktor penggerak yang kuat, demikian juga Pemerintah Kabupaten Administrasi Kepulauan Seribu (independent variables), berdasarkan diagram model struktural kelembagaan berada pada level 6 . Pada level 5 Pemerintah Propinsi DKI Jakarta dan Balai Taman Nasional Kepulauan Seribu (independent variables) juga merupakan lembaga yang memberikan pengaruh kuat. Hal ini mengindikasikan bahwa untuk efektivitas dan keberlanjutan dalam pengelolaan 
Kawasan Taman Nasional Kepulauan Seribu bergantung pada ke-empat lembaga tersebut. Berdasarkan kajian pengaruh kelembagaan, maka dukungan oleh pemerintah melalui Kementerian Kehutanan terhadap Balai Taman Nasional sangat menentukan efektivitas pengelolaan.

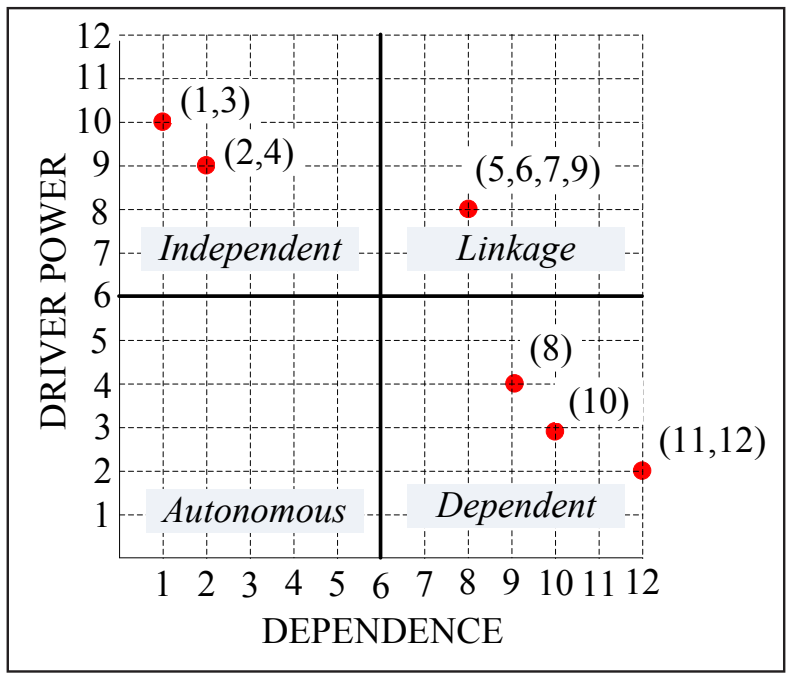

Gambar 2. Matriks Driver Power-Dependence Kelembagaan (Transivity 92,6\%).

Figure 2. Matrix of Institutional Driver PowerDependence (Transivity 92,6\%).

Perencanaan pembangunan di Kepulauan Seribu ditetapkan oleh Pemda DKI Jakarta, berdasarkan ketentuan pada Undang-undang Nomor 34 Tahun 1999 pasal 4 yang menyatakan bahwa kewenangan otonomi berada pada Propinsi DKI Jakarta bukan Kabupaten dan Kota seperti ketentuan dalam UU Nomor 32 Tahun 2004 tentang Pemerintahan Daerah. Namun Kabupaten Administrasi Kepulauan Seribu diberi kewenangan dalam mengatur wilayahnya dan bertanggung jawab secara langsung kepada Pemerintah Propinsi DKI Jakarta.

Kementerian Kelautan dan Perikanan, Masyarakat/nelayan, Perguruan tinggi dan Lembaga Kemasyarakatan Non Formal (SPKP, APL dan Sentra Penyuluh) masuk dalam sektor III (Linkage) dari sistem, artinya peubah dalam sektor ini harus dikaji secara hati-hati, sebab hubungan antar peubah tidak stabil. Setiap tindakan pada peubah tersebut akan memberikan dampak terhadap peubah lainnya dan umpan balik pengaruhnya bisa memperbesar dampak (Marimin, 2009). Dampak yang dimaksud adalah dapat memperbesar peluang keberhasilan program pengelolaan, dimana Kementerian Kelautan dan Perikanan melalui programnya melalui Suku Dinas
Kelautan dan Pertanian, perguruan tinggi yang melalui riset dan teknologi, serta masyarakat dan lembaga kemasyarakatan non formal dapat menunjang upaya pengelolaan melalui kerjasama dengan pemerintah daerah maupun dengan pihak pengelola. Walaupun demikian sub elemen dalam sektor linkage memiliki ketergantungan pada faktorfaktor kunci independent.

Sub elemen Lembaga Swadaya Masyarakat (L8), LIPI (L10), Stasiun Meteorologi Maritim Tanjung Priok (L11), dan Badan Informasi Geospasial (L12) masuk dalam sektor Dependent (sektor II) serta berada pada level 3, level 2 dan level 1 yang berdasarkan kajian pengaruh kelembagaan, kurang berpengaruh terhadap kebijakan pengelolaan taman nasional. Walaupun demikian sub elemen yang masuk dalam sektor dependent ini dapat memberikan informasi maupun data penunjang untuk pengelolaan, namun pengaruh secara langsung yang berkaitan dengan kebijakan seperti yang dapat dilakukan oleh lembaga yang berpengaruh kuat di sektor independent, tidak terlalu kuat. Ketergantungan sub elemen L8, L10, L11, dan L12 terhadap lembaga di sektor independent tidak ada, walaupun sering terjadi kerjasama dalam bidang penelitian.

\section{Elemen Tujuan}

Analisis tujuan memperlihatkan yang menjadi sub elemen kunci adalah Kelestarian Sumber daya Taman Nasional (T1) pada posisi level 6 (Gambar 3) merupakan tujuan yang kuat pengaruhnya, namun demikian sub elemen pada level 5 dan level 4 seperti yang ditunjukkan pada Gambar 4 masuk dalam sektor IV atau sektor independent (strong driver-weak dependent variable) juga mempunyai pengaruh kuat. Sub elemen T1 menjadi tujuan utama atau faktor penggerak utama diikuti sub elemen Terjaganya Keseimbangan Ekosistem Perairan (T5), Penegakan Hukum (T9), Adanya Koordinasi Antar Kelembagaan (T10), Mengimplementasikan Strategi Pengelolaan (T11), dan Mewujudkan Kelembagaan yang Kuat (T12). Sub elemen T1 merupakan prioritas utama dalam pengelolaan taman nasional yang berdasarkan analisis kelembagaan sangat dipengaruhi oleh sub elemen Kementerian Kehutanan (L1) dan Pemerintah Kabupaten Administrasi Kepulauan Seribu (L3). Berdampak Meningkatkan Pendapatan Masyarakat (T15) pada level 3 adalah sektor dependent yang terpengaruh atau bergantung pada terwujudnya sub elemen sektor independent. Jika ditelusuri 
pada elemen kelembagaan terkait dengan sub elemen kunci tujuan, pemerintah Kabupaten Administrasi Kepulauan Seribu mendukung program transplantasi karang melalui suku Dinas Kehutanan dan Kelautan yang bermitra dengan Lembaga Kemasyarakatan Non Formal (L9), yaitu Area Perlindungan Laut (APL).

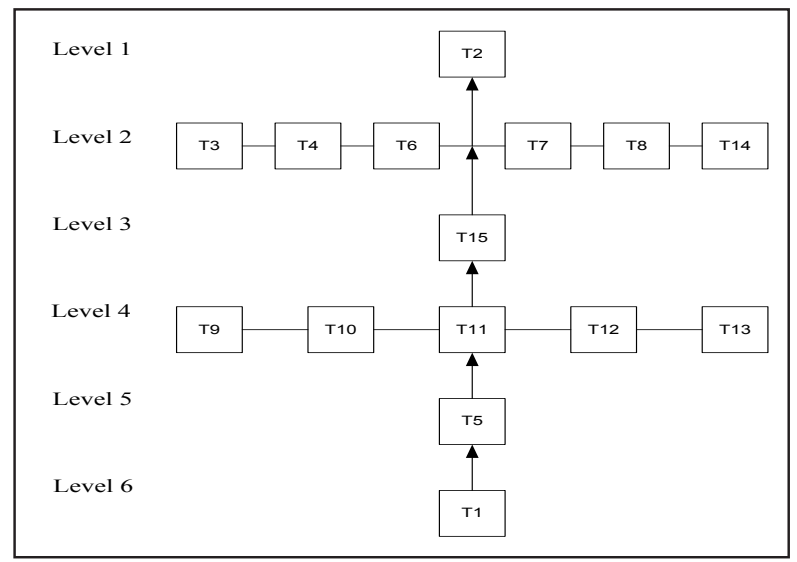

Gambar 3. Diagram Model Tujuan Program Pengelolaan Taman Nasional Kepulauan Seribu.

Figure 3. Diagram Model the Goal of Program on Management of The Kepulauan Seribu National Marine Park.

Demikian juga Kementerian Kehutanan yang membawahi Balai Taman Nasional bermitra dengan Sentra Penyuluh Konservasi Pedesaan (SPKP) untuk mendukung program penanaman mangrove di kawasan taman nasional. Hasil analisis menunjukkkan bahwa kedua lembaga yang berpengaruh, mempunyai kepentingan yang sama terkait dengan pengelolaan sumber daya.

Sektor III atau sektor linkage terdapat sub elemen Berdampak Pada Produksi Ikan Berkelanjutan (T3), Berdampak Memperluas Lapangan Kerja (T4), Berdampak Terhadap Kelestarian Sumber daya Perikanan (T6),
BerdampakPeningkatan Kesejahteraan Masyarakat di Kawasan Taman Nasional (T7), Monitoring perubahan Perairan (T8), dan Berdampak Pada Peningkatan PAD/PNBP (T14).

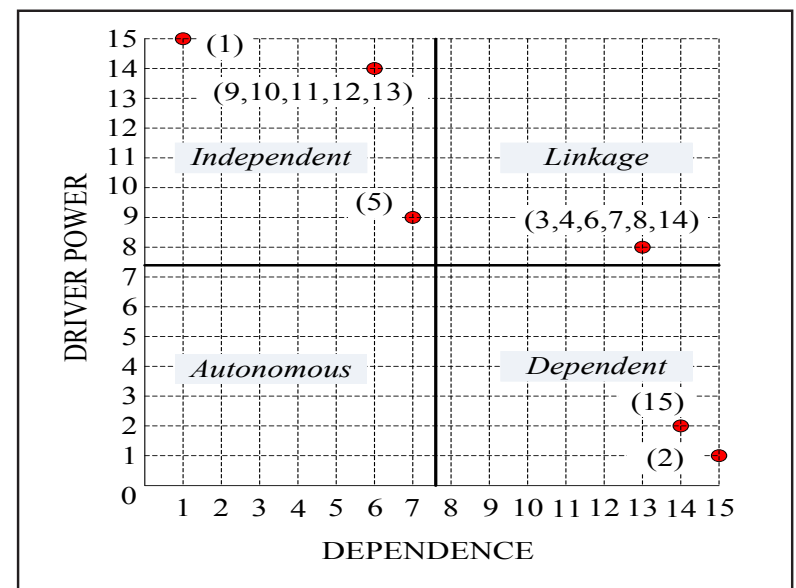

Gambar 4 Matriks Driver Power-Dependence Tujuan Program (Transivity 76,4\%).

Figure 4. Matrix Driver Power-Dependence of The Goal Program (Transivity 76,4\%).

Sub elemen dalam sektor linkage saling berkaitan satu dengan lainnya, secara teoritis tindakan terhadap peubah dalam sektor dapat memberikan dampak terhadap peubah lainnya, namun harus ditangani dengan hati-hati karena hubungan antar peubah dalam sektor ini tidak stabil. Sub elemen kunci Kelestarian Sumber daya Taman Nasional (T1) jika tercapai maka akan berdampak atau berpengaruh terhadap sub elemen lainnya dalam elemen tujuan (Tabel 2).

Adanya perbedaan persepsi terkait dengan lembaga yang terlibat yaitu Kementerian Kehutanan yang membawahi Balai Taman Nasional dan Pemerintah Kabupaten Propinsi Administrasi Kepulauan Seribu yang mendapat kewenangan dari Propinsi DKI Jakarta untuk mengelola wilayah. Hasil wawancara dengan pakar, menunjukkan

Tabel 2. Elemen Sistem dan Sub elemen Kunci Pengelolaan TNKpS.

Table 2. Element System and Sub Element Keys on the Management of TNKpS.

\begin{tabular}{lll}
\hline No. & Elemen / Element & \multicolumn{1}{c}{ Sub Elemen Kunci / Key of Sub Element } \\
\hline 1 & Kelembagaan / Institutional & - Kementerian Kehutanan / Ministry of Forestry \\
& & Pemerintah Kabupaten Administrasi Kepulauan \\
& & Seribu / Local Government of District \\
& & Administration Kepulauan Seribu \\
2 & Tujuan program / & Kelestarian sumberdaya taman nasional / \\
& Programme objective & Resource sustainability of national park \\
\hline
\end{tabular}


bahwa perbedaaan terletak pada undang-undang yang menjadi dasar lembaga-lembaga yang terlibat dalam pengelolaan. Kementerian Kehutanan dalam mengelola Kawasan Taman Nasional Kepulauan Seribu berdasarkan kewenangan seperti yang termaktub dalam Undang-Undang Nomor 5 Tahun 1990 bahwa pengelolaan kawasan pelestarian alam yang meliputi taman nasional merupakan kewajiban pemerintah. Sementara Pemerintah Kabupaten Administrasi Kepulauan Seribu menjadikan dasar pengelolaan kawasan pada Undang-Undang Nomor 32 Tahun 2004 pasal 18 yang menyatakan bahwa daerah yang memiliki wilayah laut diberikan kewenangan untuk mengelola sumber daya di wilayah laut, meliputi eksplorasi, eksploitasi, konservasi, dan pengelolaan kekayaan laut.

Terkait dengan kegiatan masyarakat yang bersifat merusak di Kawasan Taman Nasional Kepulauan Seribu dan solusi bagi permasalahan, maka harmonisasi dalam merumuskan kebijakan dan implementasinya sangat dibutuhkan. Hasil analisis kelembagaan dengan metode ISM menunjukkan empat lembaga dalam sektor independent mempunyai pengaruh kuat, yang untuk mencapai efektivitas dalam perannya menurut Sholahuddin (2001) lembaga-lembaga yang terlibat dalam pengelolaan harus memperhatikan tiga aspek, yaitu 1) aspek struktur organisasi yang fleksibel dalam menghadapi kondisi tertentu dan mampu untuk menyesuikan terhadap lingkungan yang dihadapi, 2) aspek kejelasan fungsi dari setiap lembaga berdasarkan tugas dan fungsi masingmasing, 3) aspek tata nilai atau norma, dalam setiap organisasi harus mempunyai tata nilai yang dipatuhi oleh elemen-elemen dalam organisasi.

Secara garis besar untuk pemanfaatan yang lestari diperlukan kelembagaan yang kuat serta efektif dan efisien. Pengelolaan kawasan taman nasional akan tercapai jika perbedaan perspektif dalam pengelolaan kawasan dapat diatasi dalam rangka untuk keberlanjutan jasa ekosistem. Diperlukan pemahaman yang mendalam dan pengelolaan yang bijak dalam mencapai tujuan bersama untuk jangka pendek maupun jangka panjang. Pemanfaatan jasa ekosistem yang berlebihan dan bersifat merusak tentunya akan berdampak dalam jangka panjang dengan berkurangnya ketersediaan jasa tersebut untuk masa mendatang. Kelembagaan yang efektif dan efisien dapat mengatur akses terhadap sumber daya melalui mekanisme kesetaraan, keadilan dan keselarasan. Memahami perbedaan persepsi dalam pengelolaan sumber daya antara kelembagaan yang terlibat, serta faktor yang dapat menyebabkan perubahan dalam ekosistem dan jasa ekosistem merupakan suatu hal yang sangat penting untuk dapat merumuskan kebijakan yang memiliki dampak positif dan sekaligus meminimalisir dampak negatif.

Salah satu permasalahan berkaitan dengan perbedaan kebijakan adalah perijinan untuk kegiatan usaha budidaya perikanan skala besar di Zona Pemanfaatan Wisata Taman Nasional oleh Pemerintah daerah yang mengembangkan pola pemanfaatan, berbenturan dengan kebijakan pengelolaan BTNKpS yang menerapkan sistem zonasi yang melarang adanya kegiatan budidaya skala besar dalam zona tersebut. Perbedaan tersebut bersumber pada undang-undang yang menjadi dasar kebijakan BTNKpS yaitu UU Nomor 5 Tahun 1990 yang belum mengakomodir kegiatan perikanan dalam kawasan konservasi dan Pemerintah Daerah dengan UU Nomor 32 Tahun 2004 pasal 18 ayat 1 yang menyatakan kewenangan daerah untuk mengelola kawasan pesisir.

Kegiatan yang bersifat merusak di Kawasan Taman Nasional Kepulauan Seribu adalah aktifitas penambangan batu karang untuk kebutuhan reklamasi dan pembangunan rumah warga sudah berlangsung selama beberapa tahun sebelumnya. Kegiatan penambangan hanya akan terhenti pada pertengahan Bulan Desember sampai Bulan Januari saat musim barat berlangsung laut bergelombang cukup tinggi atau cuaca buruk. Aktivitas yang cukup tinggi terjadi pada musim timur pada saat laut relatif tenang dan tidak bergelombang. Aktivitas penambangan berlangsung sekitar 11 bulan dalam setahun, yang diprediksi dalam setahun degradasi terumbu karang dalam kawasan Taman Nasional Kepulauan Seribu sebesar 6.097,3 $\mathrm{m}^{3}$, dengan nilai Rp. 640.216 .500 berdasarkan harga jual penambang kepada masyarakat. Di lain pihak Pemerintah Propinsi DKI Jakarta menganggarkan dana untuk rehabilitasi terumbu karang berupa proyek transplantasi karang sebesar kurang lebih Rp. 1.000.000.000 setiap tahun. Hasil perhitungan memperlihatkan kawasan Taman Nasional Kepulauan Seribu kehilangan hamparan karang sepanjang 18.312,6 m yang setara dengan 1,83 hektar setiap tahunnya. Upaya rehabilitasi dapat efektif dari segi anggaran dan waktu apabila penelitian yang berkaitan dengan data kemampuan alami terumbu karang dalam kawasan Kepulauan Seribu untuk perbaikan diri dalam jangka panjang terus dilakukan. 
Strategi yang dapat dikembangkan dalam pengelolaan, yaitu:

1. Peninjauan dan revisi Undangundang Nomor 32 Tahun 2004 tentang Pemerintahan Daerah dan Undangundang Nomor 5 Tahun 1990 tentang Konservasi Sumber Daya Alam Hayati dan Ekosistemnya. Substansi yang perlu direvisi adalah pasal 17 dan 18 dalam UU Nomor 32 Tahun 2004 belum mengakomodir kegiatan perikanan dan lebih menitik-beratkan pada pengelolaan sumber daya laut, sementara UU Nomor 5 Tahun 1990 lebih terfokus pada konservasi kehutanan/wilayah daratan dan belum mengatur pengelolaan konservasi pesisir dan laut.

2. Peninjauan dan revisi Peraturan Daerah DKI Jakarta Nomor 1 Tahun 2012 pasal 186 yang hanya melarang penambangan pasir laut, sementara Rencana Pengelolaan Taman Nasional Kepulauan Seribu Tahun 1999 - 2019 melarang penambangan pasir dan batu karang.

3. Pemanfaatan kawasan perairan dalam kawasan Taman Nasional oleh kegiatan masyarakat maupun pemangku kepentingan lainnya harus ditujukan untuk menunjang fungsi kawasan.

4. Pengawasan dan Pengendalian penambangan karang dan pasir disertai dengan pengadaan material batu dan pasir melalui kebijakan subsidi oleh pemerintah daerah.

5. Pendidikan dan keterampilan masyarakat dalam kawasan konservasi ditingkatkan disertai upaya pengembangan mata pencaharian alternatif bagi masyarakat.

6. Kolaborasi dalam pengelolaan sumber daya hayati antara pemerintah daerah dan BTNKpS.

\section{KESIMPULAN DAN IMPLIKASI KEBIJAKAN}

\section{Kesimpulan}

Berdasarkan analisis kelembagaan dengan menggunakan ISM-VAXO diperoleh struktur kelembagaan yang paling berperan terhadap keberlanjutan pengelolaan Taman Nasional Laut Kepulauan Seribu, adalah Kementerian Kehutanan melalui Balai Taman Nasional Kepulauan Seribu dan Kabupaten Kepulauan Seribu yang secara yuridis kawasan TNKpS berada dalam wilayahnya. Kewenangan BTNKpS berdasarkan UndangUndang Nomor 5 Tahun 1990 berkewajiban dan bertanggung jawab dalam pengelolaan taman nasional, dan Pemerintah Kabupaten Administrasi Kepulauan Seribu berdasarkan pada UndangUndang Nomor 32 Tahun 2004, Undang-Undang Nomor 26 Tahun 2007, Undang-Undang Nomor 27 Tahun 2007, dan Perda Nomor 1 Tahun 2012 yang intinya kewenangan daerah untukmengelola sumber daya di wilayahnya. Perbedaan undang-undang dalam pengelolaan TNKpS oleh kelembagaan yang berperan, melatar belakangi perbedaaan dalam pengambilan kebijakan, sehingga kondisi dilapangan sering terjadi perbedaan berkaitan dengan implementasi kebijakan.

\section{Implikasi Kebijakan}

Sub elemen dari Elemen Tujuan Program yang dapat dirujuk sebagai kebijakan pengelolaan bersama kedua kelembagaan tersebut adalah Kelestarian Sumber daya Taman Nasional. Saran yang dapat dikemukakan untuk pemangku kepentingan adalah harmonisasi kebijakan dan program pengelolaan berbasis ekologi, sosial, ekonomi dan kelembagaan untuk kawasan Kepulauan Seribu dapat mewujudkan pengelolaan yang berkelanjutan. Harmonisasi dapat diimplementasikan dalam kebijakan Pemerintah Propinsi DKI yang tertuang dalam Peraturan Daerah Nomor 1 Tahun 2012 tentang Rencana Tata Ruang Wilayah 2030 dengan Review Rencana Pengelolaan Taman Nasional Kepulauan Seribu periode tahun 1999-2019 BTNKpS.

\section{DAFTAR PUSTAKA}

Amanah, S. 2004. Perencanaan Strategis Pengelolaan Sumber daya Pesisir Terpadu di Kelurahan Pulau Panggang Kecamatan Kepulauan Seribu Utara, Kabupaten Kepulauan Seribu Provinsi DKI Jakarta. Buletin Ekonomi Perikanan Vol. 5. (2).

Balai Taman Nasional Kepulauan Seribu (BTNKpS). 2011. Review Rencana pengelolaan Taman Nasional (RPTN) Kepulauan Seribu Periode Tahun 1999-2019. Kementerian Kehutanan. Direktorat Jenderal Perlindungan Hutan dan Konservasi Alam Balai Taman Nasional Kepulauan Seribu. Jakarta. 
Badan Perencanaan dan Pembangunan Daerah (Bappeda) DKI. 2001. Pemantapan rencana tata ruang wilayah Kabupaten Administrasi Kepulauan Seribu. Laporan Akhir Tahun Anggaran 2001. Pemerintah Propinsi Daerah Khusus Ibukota Jakarta.

Cadoret, A. 2009. Conflict dynamics in Coastal Zones: a perspective using the example of Languedoc-Rousillon (France). J Coast Conserv 13:151-163

English, S., C. Wilkinson \& V. Baker. 1997. Survey Manual for Tropical Marine Resources. ASEAN-Australian Marine Project. Australia.

Hilyana, S. 2011. Optimasi pemanfaatan ruang kawasan konservasi Gili Sulat-Gili Lawang Kabupaten Lombok Timur. [Disertasi]. Bogor. Sekolah Pascasarjana Institut Pertanian Bogor.
Gomes, V.F., A. Barocco, A.R. Pereira, C.S. Reis, H. Calado, J.G. Ferreira, M.D.C. Freitas \& M. Biscoito. 2008. Basis for a national strategy for integrated coastal zone management-in Portugal. J. Coast Conserv 12: 3-9

Marimin, K. 2009. Aplikasi teknik pemodelan interpretasi struktural (Intrepetive Structural Modelling). Materi Mata Kuliah Interpretive Structural Modelling. Sekolah Pascasarjana Institut Pertanian Bogor.

Saxena, J.P., Sushil \& P. Vrat. 1992. Hierarchy and classification of program plan elements using interpretative structural modeling: a case of study of energy conservation in the Indian cement industry. System Practice. 5(6): $651-670$

Sholahuddin, A. 2001. Analisis Kelembagaan Pengembangan Agroindustri (Studi Kasus Kabupaten Tebo, Jambi). Thesis. Bogor. Sekolah Pascasarjana Institut Pertanian Bogor. 